\title{
LATE PLEISTOCENE VERTEBRATES FROM THREE-FORKS CAVE, ADAIR COUNTY, OKLAHOMA OZARK HIGHLAND
}

\author{
Nicholas J. Czaplewski ${ }^{1}, \mathrm{C}$, Kyler J. Rogers ${ }^{1}$, and Clayton Russell ${ }^{2}$
}

\begin{abstract}
We report on an assemblage of vertebrate fossils from a limestone cave in the southwestern portion of the Ozark Highlands. The fauna includes several extinct, large-bodied mammalian taxa including Megalonyx jeffersonii (Jefferson's ground sloth), Canis dirus (dire wolf), Arctodus simus (short-faced bear; two individuals), and Equidae (extinct horses), which indicate a late Pleistocene age. In addition, there is a variety of extant vertebrates including a fish, Aplodinotus cf. grunniens (freshwater drum), unidentified Anura (frogs and toads) and Caudata (salamanders), Terrapene sp. (box turtles), cf. Ophisaurus (legless lizards), Colubroidea and Crotalidae (non-venomous snakes and pit vipers), Bubo virginianus (great horned owl), and at least 12 other mammals: Sorex sp. (long-tailed shrews), Perimyotis subflavus (tricolored bat), Eptesicus fuscus (big brown bat), Myotis grisescens (gray myotis), possibly other species of Myotis, Vulpini (foxes), several rodents, Geomys sp. (pocket gophers), Chaetodipus or Perognathus (pocket mice), Peromyscini (native mice), Neotoma cf. floridana (eastern wood rat), Microtus cf. ochrogaster (prairie vole), and, Sylvilagus sp. (cottontail rabbits). An earlier report provided a tentative age of one of the Arctodus simus of about 34,000 years ago (late Pleistocene, Rancholabrean). Among the 23 taxa in the Three-Forks Cave assemblage, two species are added to the Oklahoma Ozark Highland paleofauna: freshwater drum and great horned owl. One extralimital taxon, the pocket mouse Chaetodipus or Perognathus, is present in the assemblage. Numerous remains of juvenile bats of Myotis grisescens and Eptesicus fuscus provide evidence that these species used Three-Forks Cave as a maternity site. Large crater-like pits in the floor of Three-Forks Cave and other caves in the vicinity may represent ancient and modern beds of the short-faced bear and black bear, respectively.
\end{abstract}

\section{Introduction}

Late Pleistocene faunas are relatively well known from localities in the Ozark Highlands of central North America, especially those recovered from caves. In the online database for North American late Quaternary mammal localities, FAUNMAP II-NEOTOMA (FAUNMAP Working Group, 1994; http://www.ucmp.berkeley.edu/faunmap/about/index. $\mathrm{html}$ ), 36 such vertebrate faunal assemblages are known in the Missouri Ozarks and four in the Arkansas Ozarks. No localities from the Oklahoma portion of the Ozark Highland are listed in FAUNMAP II-NEOTOMA, but three cave sites were overlooked. These are Gittin' Down Mountain Cave (an alternative name for Three-Forks Cave) with one species (Puckette, 1976; Smith and Cifelli, 2000), Sassafras Cave with nine taxa (Czaplewski et al., 2002); and CZ-9 Cave (aka Dressler Cave) with three taxa (Czaplewski and Puckette, 2015). Three-Forks Cave, with 23 taxa described herein, substantially adds to the Pleistocene fauna of the Ozark Highland in Oklahoma and bolsters knowledge of the Quaternary history of this physiographic region.

A single tooth of the short-faced bear, Arctodus simus, was reported from Gittin' Down Mountain Cave, Okla. by Puckette (1976). The specimen, a worn right m2, was deposited in the University of Arkansas Museum as UAM 75839-1. We report additional remains of this same individual bear, as well as a second individual and an associated late Quaternary vertebrate assemblage from the same cave, aka Three-Forks Cave. The Arctodus molar from Three-Forks Cave was used by Schubert (2010) in his study of the chronology of late Quaternary Arctodus finds in North America. He provided a date of $34,063 \pm 460$ rcybp (NZA-27,734; $14 \mathrm{C}$ range at 2 sigma: 33,143 to 34,983 ybp) on the Arctodus $\mathrm{m} 2$ dentine, but noted that "The C:N ratio of 2.4 falls outside the range of well-preserved collagen.... Further, the percent $C$ is particularly low, and these factors imply that the collagen from the sampled dentine is degraded. While this does not indicate a 'bad' date, it does mean that some degree of caution should be associated with it" (Schubert, 2010: p. 191). If the Three-Forks Cave Arctodus date is taken at face value, it is approximately equivalent to the oldest directly-dated Arctodus simus in North America from Island Ford Cave, Virginia (in which the collagen was well preserved; Schubert 2010). We, tentatively, use Schubert's (2010) 34 ka date as the approximate age for the Three-Forks Cave assemblage, while pointing out that fossils were collected from several different parts of the cave, and they are likely to be diachronous (Semken et al., 2010).

Three-Forks Cave is on private property adjacent to the Donald R. Russell Cave Preserve, in Adair County, Okla. (Fig. 1), and it is recorded as Oklahoma Museum of Natural History (OMNH) locality V1474. It developed within limestone

${ }^{1}$ Oklahoma Museum of Natural History, 2401 Chautauqua Avenue, and Department of Biology, University of Oklahoma, Norman, OK 73072 ,

USA.

${ }^{2}$ Chair, Donald R. Russell Cave Preserve; Rt. 1 Box 1459, Stilwell, OK 74960, USA.

'Corresponding Author: nczaplewski@ou.edu 


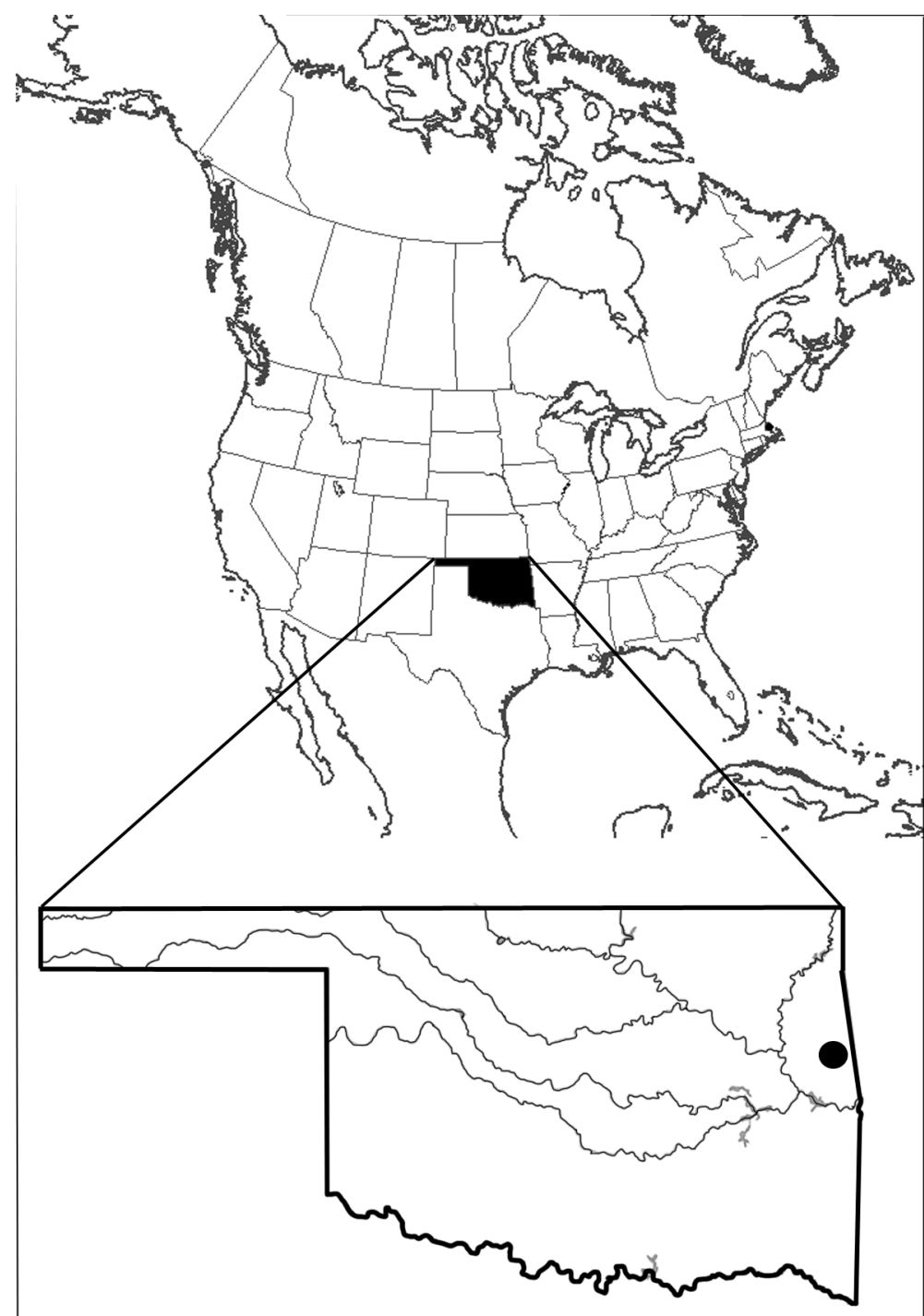

Figure 1. Locator map of central North America with state of Oklahoma in black, enlarged below, showing location of Three-Forks Cave (dot). of the Pitkin Formation, late Mississippian age; the formation is about $18 \mathrm{~m}$ thick in this area. Within the cave there are two main bone accumulation areas, the Drain (Fig. 2A) and the Second Parachute Room (Fig. 2B), as well as a few additional isolated occurrences of fossils elsewhere (Fig. 2C, 2D). The Drain is an area in which the small stream running through this part of the cave drops through the floor downstream of several rimstone dams. Numerous small bones that had been cemented into the floor are exposed. From the dams, the stream drops into lower level passages too small to be entered. Many of the larger vertebrates, each of which was represented by an isolated bone, and most of the microvertebrate fossils came from the Drain area (Fig. 2A). The Second Parachute Room is named for a fringed canopy speleothem in the passage. The more complete fossils of two short-faced bears came from the Second Parachute Room (Fig. 2B), while the other bear bones came from a passage not far from the Drain (Fig. 2D). The provenience data for all cave fossils were recorded with individual, cataloged specimens and are also recorded below in the systematic accounts (under Materials). The preservation and condition of fossils in these distinctive areas of the cave differs somewhat, and even varies within one area (microvertebrates in the Drain). Although the temporal span during which fossils accumulated in these cave areas probably also differ, the assemblage is considered a single local fauna.

Some Three-Forks Cave fossils were collected by Clayton and Donald Russell in the mid-late 20th century. We did further collecting in April, 2003, May, 2004, and May, 2006, resulting in a total of 988 cataloged specimens. Most of the bones from the Drain are dark brown to reddish brown, and many are encrusted in yellowish-buff to brown carbonate with included pebbles and cobbles. In contrast, bones from the Second Parachute Room are mostly light in color with dark-tinted edges, where they had been partly exposed by foot traffic in a walking passage. These bones are more fragmentary and were found in mud on the cave floor. The isolated bones from other areas of the cave vary in color. The dissimilar preservation probably reflects varying conditions in different areas of the cave.

\section{Methods}

Specimens were collected on three trips during 2003, 2004, and 2006, using rock hammer, awls, trowels, and chisels. Fossils were selectively removed from carbonate and gravelly mud deposits in the wet crawlways and stream beneath the floor and a natural bridge at the Drain, and in the floor of the Second Parachute Room. They were also removed from rock and mud in the floor at a few other passages. Fossils were wrapped, bagged, and labeled for transport to the $\mathrm{OMNH}$, where they underwent preparation and cleaning. Bulk samples of sedimentary deposits amounting to perhaps $100 \mathrm{~kg}$ from the Drain and Second Parachute Room were bagged for transport and processed to recover microvertebrate fossils by standard screenwashing methods using tandem screen boxes of $1.5 \mathrm{~mm}$ (coarse) and 0.6 mm (fine) mesh (Cifelli, 1996).

Measurements of larger specimens were made with dial calipers; smaller specimens were measured with an eyepiece reticle in an Olympus SZX9 stereomicroscope. All measurements are in millimeters. Standard measurements of teeth are abbreviated APL for greatest anteroposterior length of crown, and TW for greatest transverse width of crown. Other measurements are described in the text and tables. Of the total of 988 vertebrate specimens recovered from 


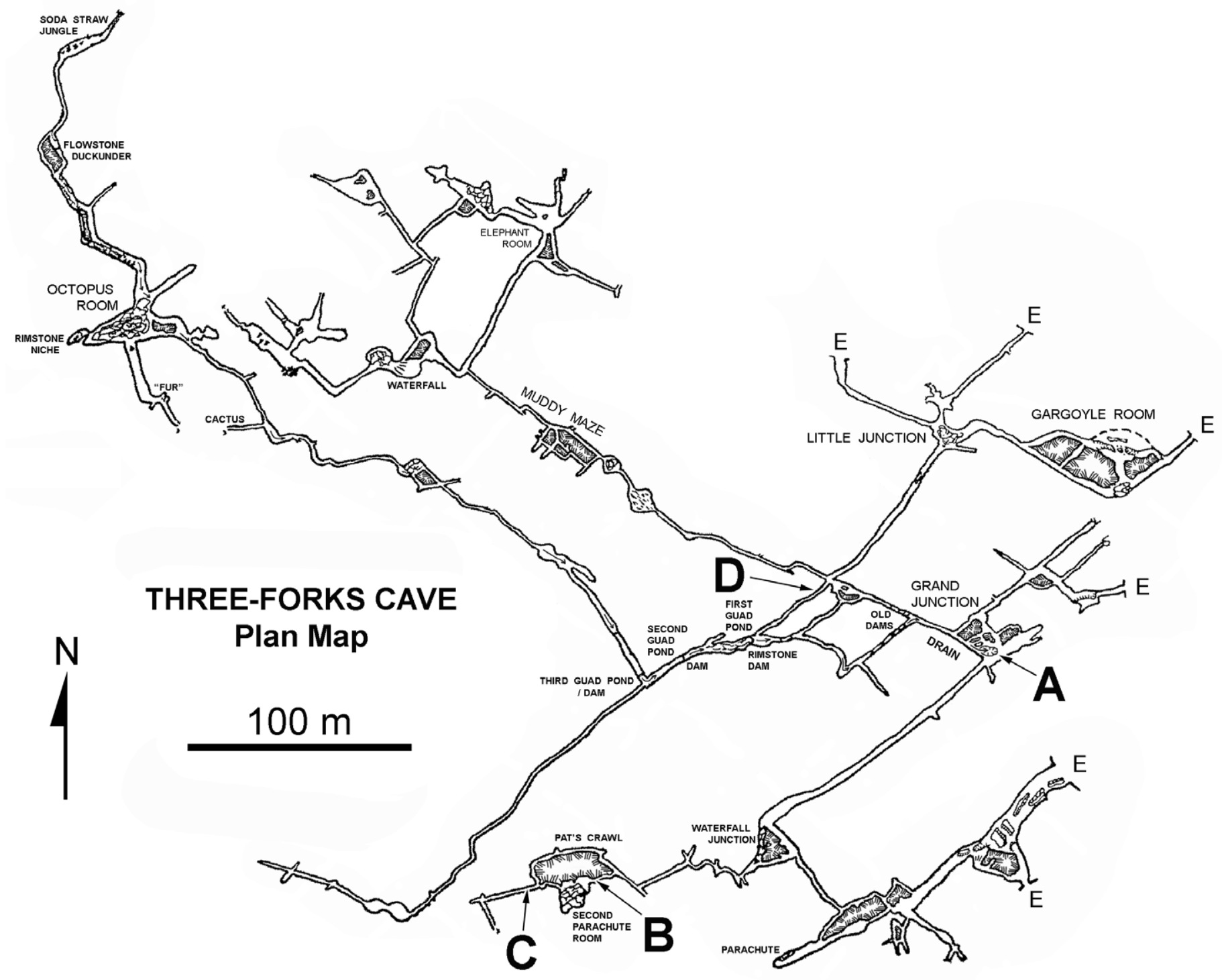

Figure 2. Plan map of Three-Forks Cave, Adair County, Oklahoma, by Donald Russell, 1976, indicating areas in which fossils in this report were recovered. Abbreviations: A, main concentration of fossils, including most microvertebrates, within the Drain; B, concentration of Arctodus simus bones and a few microvertebrates near Second Parachute Room; C, isolated horse bone; D, isolated Arctodus bones; E, entrances; Small Arrows within cave passages indicate present stream flow to the Drain.

Three-Forks Cave, about 840 are bats ( $85 \%$ of cataloged specimens) of which 700 were identified only to the family level. Herein we list the taxa recovered, with discussion of only those identifiable to lower-level categories (family, genus, or species) or with implications of paleontological significance. A complete inventory of cataloged and identified vertebrate skeletal elements recovered from Three-Forks Cave, Adair County, Okla., is available from the Department of Vertebrate Paleontology at the OMNH.

\section{Systematic Paleontology}

\section{Osteichthyes}

\section{Sciaenidae}

Aplodinotus cf. grunniens (freshwater drum)

Material: OMNH 78544, partial premaxilla (Fig. 3A) from the Drain.

The lateral branch of the bone and crowns of the teeth are broken away, but the remainder of the premaxilla, with cuplike tooth bases, is nicely preserved. A few other fish bones, all from the Drain, were recovered but were not identifiable to family. We did not have access to comparative osteological fish specimens. Morphology of the premaxilla resembles that of other sciaenids: having the ascending process rising at a right angle to the alveolar process, ascending process slender and straight and closely appressed to, but separated from, the articular process by a distinct notch, and 

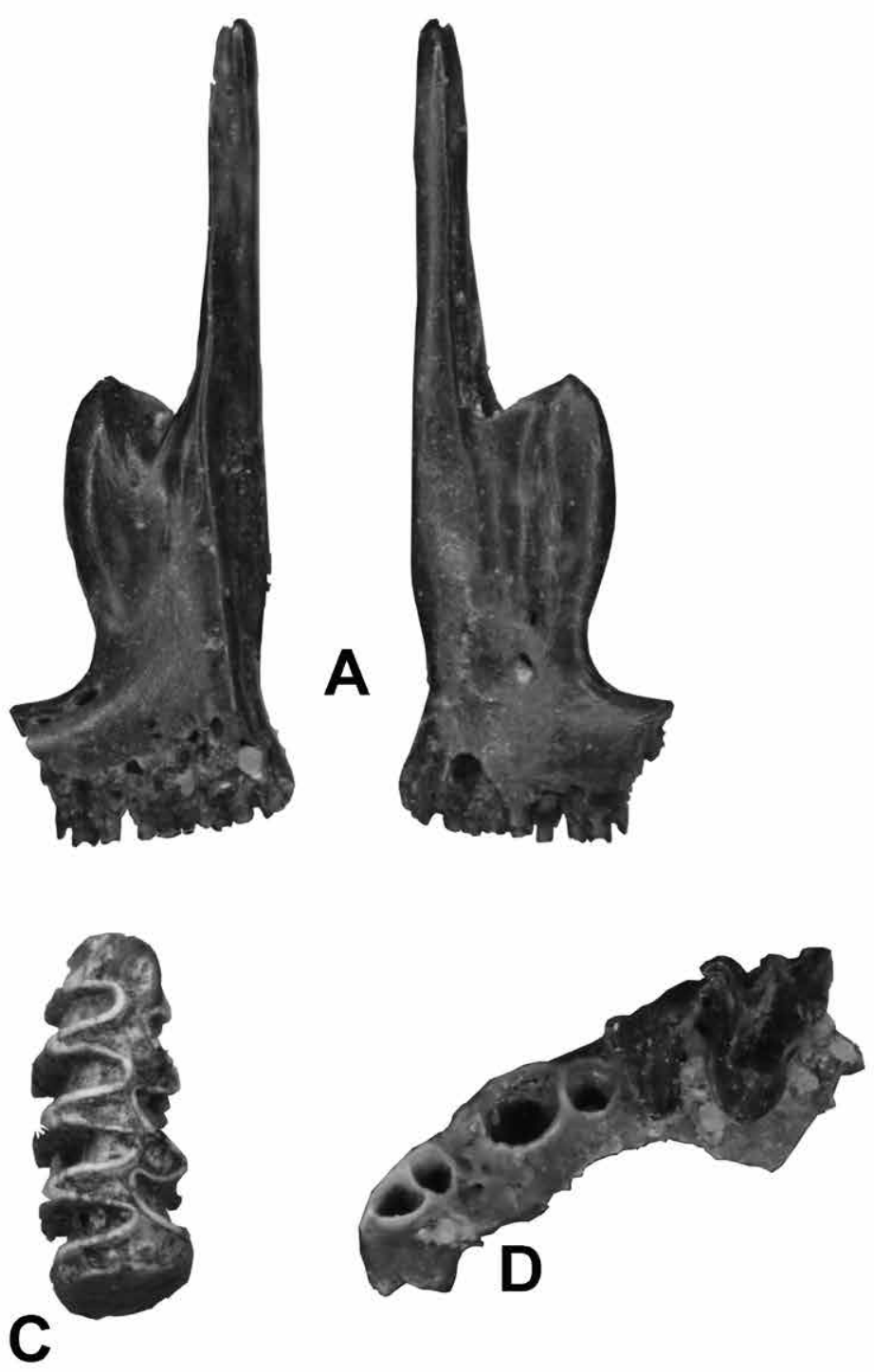

\section{$3 \mathrm{~mm}$}
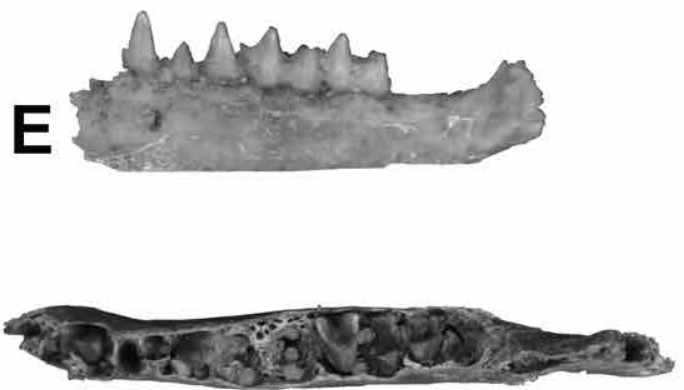

$\mathbf{F}$

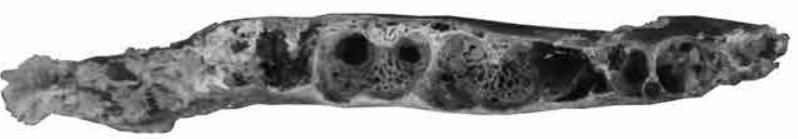

G

\section{$3 \mathrm{~mm}$}
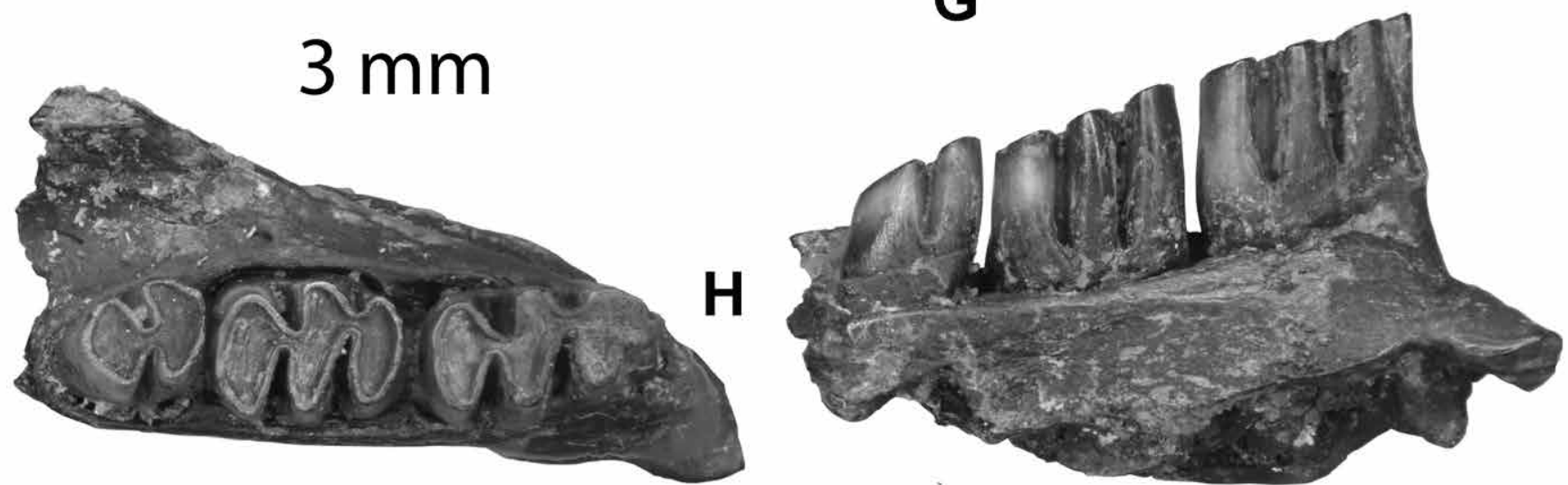

Figure 3. Selected microvertebrate fossils from Three-Forks Cave, Oklahoma. A, Aplodinotus cf. grunniens right premaxilla (OMNH 78544) in medial and lateral views. B, Sorex sp. rostrum fragment (OMNH 78524) in labial and occlusal views. C, Microtus cf. ochrogaster m1 from dentary fragment (OMNH 78353) in occlusal view. D, Perimyotis subflavus rostrum fragment with empty alveoli and P4-M1 (OMNH 77789 ) in occlusal view; E, $P$. subflavus dentary with c1-m2 (OMNH 77695) in labial view. F, Myotis grisescens juvenile dentary with deciduous and permanent tooth alveoli and developing teeth (OMNH 77728) in occlusal view. G, Eptesicus fuscus juvenile dentary showing deciduous tooth alveoli and developing permanent teeth (OMNH 77729) in occlusal view. $\mathrm{H}$, Neotoma cf. floridana dentary fragment with m1-m3 (OMNH 77700) in occlusal and labial views. Scale bar at left pertains to A, C, D, and H; scale bar at right pertains to B, E, F, and G. 
articular process about half the height of the ascending process. However, no autapomorphies of the premaxilla are recorded in Aplodinotus (Sasaki, 1989). The specimen from Three-Forks Cave matches the premaxilla of the freshwater drum illustrated by Green (1941: plate I fig. 10), Sasaki (1989: fig. 34A), and Qadri and McAllister (1967: plate II fig. 11c). The freshwater drum is distinct among the Sciaenidae as the only member of this large family to inhabit freshwater (Sasaki, 1989); all other Sciaenidae are marine. The recent native distribution of $A$. grunniens includes relatively large bodies of water in the Mississippi River drainage and Great Lakes regions over much of the eastern United States, including the entire Ozark Highlands and surrounding regions (Page and Burr, 1991). If the fossil actually represents the living species and not an unrecognized, extinct one, this is the first fossil record of $A$. grunniens from the Ozark Highlands. The species is relatively common as a Pleistocene fossil in the United States (Jacquemin et al., 2016) and is known as a fossil elsewhere in Oklahoma in the early Pleistocene (Irvingtonian land mammal age) Berends local fauna (Smith, 1954). However, because of our inability to find autapomorphic characters in the fossil, its paleogeographic significance is dubious.

Amphibia

Anura

Sixteen skeletal elements, including several ilia, from an undetermined number of individual frogs or toads were recovered from the Drain but lacked morphological characters by which they could be further identified.

Caudata

A total of 45 salamander skeletal elements including several vertebrae were recovered from the Drain. The vertebrae of salamanders are considered taxonomically useful (Holman, 1995). They are identifiable as salamanders, based on the hourglass-shaped centrum and two elongated rib-bearing processes on either side, and on being amphicoelous or with ossified caps on some cotyles as in Plethodontidae. The specimens from Three-Forks Cave could not be identified to family level, but both simple and complex forms noted by Holman (1995) are represented. They are important in providing a basis for inclusion of Caudata in the faunal list.

Reptilia

Chelonia

Emydidae

Terrapene sp. indet. (box turtle)

Material: OMNH 77923, costal bone from the Drain.

The costal is long and narrow, parallel-sided along the sutures with adjacent costals, and curved to indicate a highdomed carapace. It shows grooves proximally for parts of two overlying neural scutes, but no groove for the pleural scutes. Probably, it represents a left fifth costal. These characteristics agree with those of box turtles and differ from costals of other Quaternary genera of North American turtles (Sobolik and Steele, 1996).

Squamata

Anguidae

cf. Ophisaurus sp. (glass lizards)

Material: OMNH 78540, osteoderm from the Drain.

The osteoderm is quadrate in outline, unkeeled, thin, with a rugose surface and fairly matches the mid-trunk, dorsal osteoderms of various anguids (Mead et al., 1999). Given the intra- and interindividual morphological variation in osteoderms of these lizards, we can only tentatively refer the isolated specimen to cf. Ophisaurus.

Serpentes

Colubroidea indet. (non-venomous snakes)

Material: OMNH 73029-73030, two partial trunk vertebrae from the Drain.

These vertebrae are diagnostic of snakes in possessing zygosphenes and zygantra. They resemble certain North American colubroids in lacking a long, stout hypapophysis; instead they bear low, flattened, spatulate to gladiate, hemal keels (Holman, 2000).

Crotalidae (pit vipers)

Genus indet.

Material: OMNH 78545, trunk vertebra from the Drain.

This vertebra is identifiable as that of a crotalid based on the stout, long hypapophysis (Holman, 2000). The morphological variability of crotalid vertebrae is such that individual vertebrae are not reliably identifiable beyond the family level (Bell et al., 2004). The element could feasibly represent a member of either Agkistrodon or Crotalus, but is too large (neural arch width, $7.8 \mathrm{~mm}$; width across post-zygapophyses, $11.5 \mathrm{~mm}$ ) to represent a member of Sistrurus. 
Aves

Strigiformes

Strigidae

Bubo virginianus (great horned owl)

Material: OMNH 77903, complete right humerus from the Drain.

Measurements $(\mathrm{mm})$ of the specimen are: length, 132.1; width of shaft, 9.3; width of proximal end, 22.6; width of distal end, 10.9. These measurements are well within the ranges of the same measurements for the species provided in Avian Osteology - Bird Bone Identification Guide (https://royalbcmuseum.bc.ca/Natural_History/Bones/Species-Pages/GHOW.htm).

There is some damage proximally to the medial crest and internal tuberosity (tuberculum ventrale). OMNH 77903 is smaller than the humerus of the snowy owl, Bubo scandiaca, and great gray owl, Strix nebulosa, and larger than that of the barred owl, Strix varia and other small North American owls. Morphologically, the humerus differs from that of Strix owls in that the ectepicondylar prominence is papilla-shaped and is distinct from the shaft and ectepicondyle (epicondylus dorsalis) (Howard, 1929). It differs from the humerus of the related $B$. scandiaca in having the ectepicondylar prominence shorter relative to its length (Howard, 1929).

This is the first fossil record of the great horned owl in the Ozark Highlands and in Oklahoma. As a late Pleistocene fossil in North America, the species B. virginianus is widespread and recorded from sites in the Mexican states of Chihuahua and Nuevo León, and in Arizona, California, Florida, Nevada, New Mexico, Texas, Utah, and Wyoming in the United States (Miller and DeMay, 1942; Miller, 1943; Howard, 1952; Emslie, 1985; Emslie and Heaton, 1987; Hulbert, 2001; Brasso and Emslie, 2006; Harris, 2014).

\section{Mammalia}

Xenarthra

Megalonychidae

Megalonyx jeffersonii (Jefferson's ground sloth)

Material: OMNH 77904, either manual digit IV phalanx 2 or manual digit III phalanx 2, lacking the proximal epiphysis, indicating a subadult individual (Fig. 4D-H). From the Drain. Measurements (mm) are greatest depth of distal condyles, 28.7; distal width, 19.4

Because the specimen lacks the proximal epiphysis, the proximal articular surface is absent and cannot be characterized. Adjacent to the growth plate, the dorsoventral height of the bone shaft is less deep than the distal condyles and quickly shallows to a height of $17.1 \mathrm{~mm}$ before reaching the distal condyles. The distal articulation is extensive, with the condyles sweeping through an arc of more than $180^{\circ}$, with a deep groove between the condyles. A prominent dorsal pit and more modest ventral pit at either end of the groove receive the projecting processes of the ungual phalanx (Fig $4 \mathrm{D}-\mathrm{H}$ ). These characteristics are unique to xenarthran manual phalanges and the large size indicates a ground sloth. However, the incomplete nature of the bone and the similarity in certain manual phalanges of late Pleistocene North American ground sloths obscures the identification of the element. Of North American late Pleistocene ground sloths, the manual phalanx 2 of digit IV in M. jeffersonii is quite similar to the manual phalanx 2 of digit III in N. shastensis.

If OMNH 77904 is a manual digit IV phalanx 2, that element in Paramylodon harlani (Harlan's ground sloth) is rudimentary (Stock, 1925). The same element in Nothrotheriops shastensis (Shasta ground sloth) is greatly foreshortened with hardly any shaft between the proximal and distal articulations (Stock, 1925). Thus, OMNH 77904 is unlike that of these two sloths and instead resembles the bone of $M$. jeffersonii. On the other hand, if OMNH 77904 is a manual digit III phalanx 2, that element in $P$. harlani is foreshortened with hardly any shaft (Stock, 1925). The same phalanx of $M$. jeffersonii is far more robust with a mediolaterally, much wider shaft (McDonald, 1977). Thus, OMNH 77904 is unlike both of these taxa, and instead it resembles the element in N. shastensis (Paula Couto, 1976). Perhaps future ancient DNA analysis could help identify this incomplete bone.

Nothrotheriops shastensis has no late Pleistocene (Rancholabrean) records in the Ozark Highlands and no fossil record in Oklahoma (McDonald and Jefferson, 2008; a previous record of the species in western Oklahoma (Akersten and McDonald, 1991; Smith and Cifelli, 2000) is Irvingtonian, early Pleistocene, and was re-identified as Nothrotheriops texanus [McDonald and Jefferson, 2008]). If the Three-Forks Cave sloth were $N$. shastensis, it would represent a huge 980 to $1190 \mathrm{~km}$ northeastward or northward extension in its late Pleistocene range from the nearest known localities in New Mexico, USA, and Nuevo León, Mexico (McDonald and Jefferson, 2008). The numerous North American records of Wisconsin glacial age of M. jeffersonii were summarized by Hoganson and McDonald (2007). These records included several from the northern Ozark Highland in Missouri but none in the Arkansas or Oklahoma portions of the Ozarks. Thus, the Three-Forks Cave record represents the first occurrence of Jefferson's ground sloth in the southern Ozark Highlands. We assert that the record in Three-Forks Cave is inconsistent and unparsimonious as N. shastensis. This assertion is based on the known paleogeographic distribution of that species and its absence in other Ozark Highland late Pleistocene assemblages and caves, and that the fossil instead represents $M$. jeffersonii. 


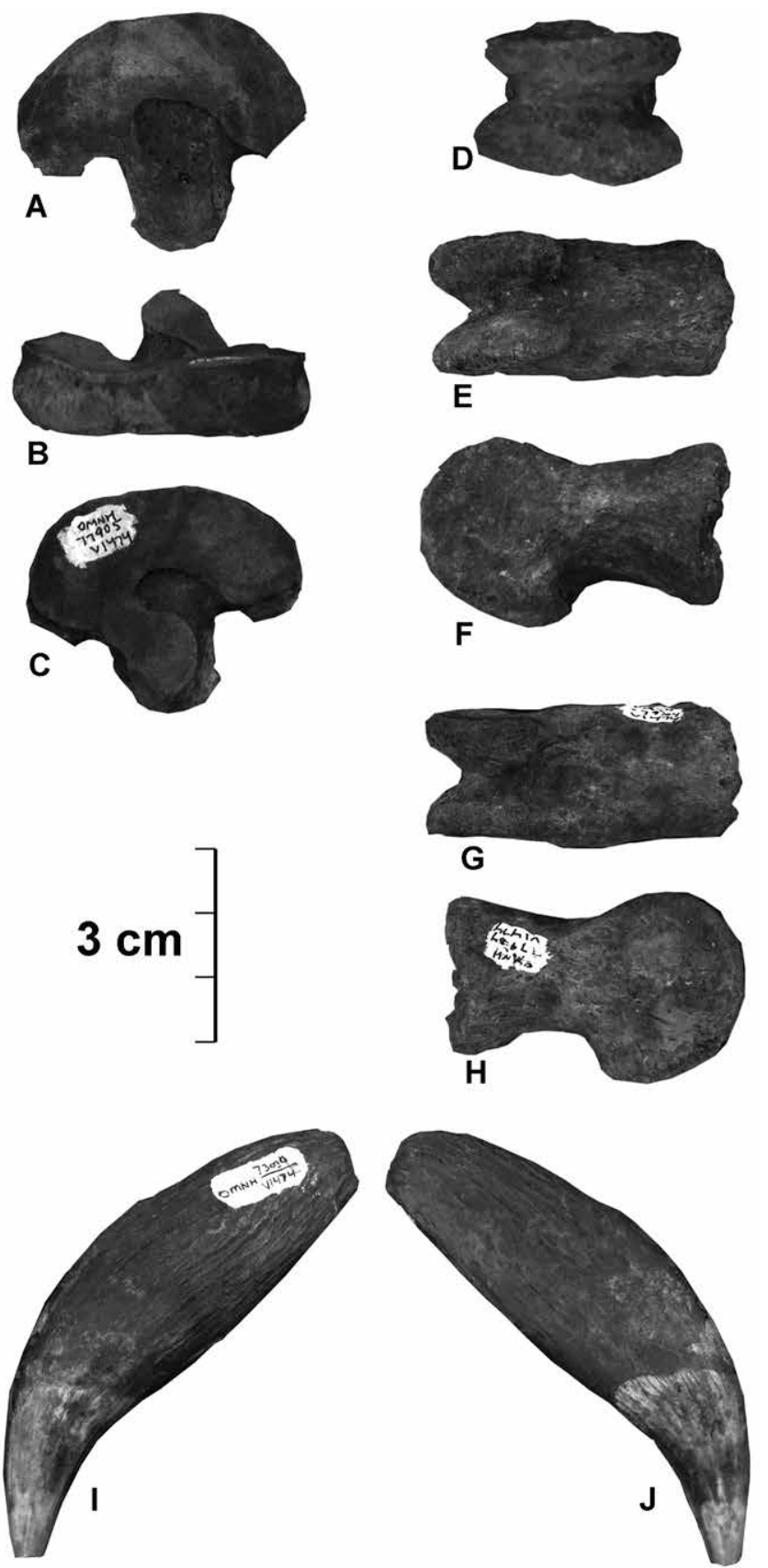

Figure 4. Fossils of large mammals from Three-Forks Cave, Oklahoma. Equidae left lateral ectocuneiform (OMNH 77905) in A, distal view; $\mathrm{B}$, anterior view; $\mathrm{C}$, proximal view. Megalonyx jeffersonii phalanx lacking proximal epiphysis (OMNH 77904) in D, distal view; E, palmar view; $\mathrm{F}$, lateral view; $\mathrm{G}$, dorsal view; $\mathrm{H}$, lateral view. Canis dirus right upper canine (OMNH 73039) in I, labial view and J, lingual view.

the cave today, but in our paleontological work we noticed no evidence of their use of it as a nursery.

Myotis grisescens (gray myotis)

Material: OMNH 72965, nearly complete cranium in a small piece of carbonate matrix, with left and right P4-M3, missing petrosals (Fig. 5); 72954, rostrum with left M2 and right M2-M3; 72955, rostrum with left P4-M3; 72958, rostrum with both P4-M3; 72960, edentulous rostrum; 77703, right half rostrum with P4-M3; 77704, rostrum with right P4 and M2; 77733, rostrum with left P4; 77734, rostrum with left C1-M3 and right P2-M3; 77735, rostrum with both P4-M3; 77736, rostrum with left $\mathrm{P} 4, \mathrm{M} 2-\mathrm{M} 3$ and right $\mathrm{M} 2 ; 77737$, rostrum with left $\mathrm{P} 4-\mathrm{M} 3$ and right $\mathrm{P} 4, \mathrm{M} 2-\mathrm{M} 3 ;$; 77832, left P4; 7295672957, right dentaries with p4-m3; 78109, left dentary with i2-m2 in a small chunk of matrix; OMNH 72969-72972,

\section{Soricomorpha}

Soricidae

Sorex sp. indet. (long-tailed shrews)

Material: $\mathrm{OMNH} 78524$, edentulous right rostrum fragment with alveoli for the entire upper tooth row except for those of the M3 (Fig. 3B), from the Drain.

The alveoli in this skull fragment indicate five unicuspids decreasing in size slightly from front to back, and with the last being distinctly smaller than the others. This condition is seen in several species, including Sorex arizonae, S. cinereus, S. haydeni, S. Iyelli, S. merriami, S. nanus, and $S$. preblei; thus, we are unable to assign the specimen to a species.

\section{Chiroptera}

Skeletal elements of bats are by far the most common fossils in the Three-Forks Cave deposits, represented by over 840 bones and isolated teeth. All pertain to Vespertilionidae, and most probably belong to Myotis, with a few pertaining to other genera. Those elements most diagnostic to the species level are discussed in detail below.

Vespertilionidae

Perimyotis subflavus (tricolored bat)

Material: OMNH 77789, left premaxilla-maxilla fragment with P4-M1 (Fig. 3D); 78214, left P4; 77851, left P4; 78516, edentulous left half rostrum; 78321, left M1 or M2; 78324, right M1 or M2; 77712, left dentary fragment with p4-m1; 77765 , right maxilla with $\mathrm{C} 1, \mathrm{P} 4-\mathrm{M} 1$; all from the Drain. OMNH 77695, left dentary with c1-m2 (Fig. 3E) from the Second Parachute Room.

All specimens include teeth showing very little wear and thus represent young adults. We observed living tricolored bats in Three-Forks Cave, but females of this species typically give birth and raise their young outside caves in summers in tree foliage, lichen-bedecked trees, bromeliads, and rock crevices (Carter et al., 1999; Veilleux et al., 2003, 2004; Perry and Thill, 2007; Farrow and Broders, 2011). As a result, the remains of juveniles are not normally found in caves.

\section{Eptesicus fuscus (big brown bat)}

Material: OMNH 78038, left dentary fragment with m1$\mathrm{m} 2 ; 77705$, left half rostrum with I2-M3; 78337, right M1 or M2; 77729 , right dentary with erupting p4 and $\mathrm{m} 3$; all from the Drain.

The dentary with erupting teeth (OMNH 77729; Fig. $3 G$ ) indicates that $E$. fuscus was using the cave as a nursery roost in the late Pleistocene. The species still utilizes ery roost in the late Pleistocene. The spec 


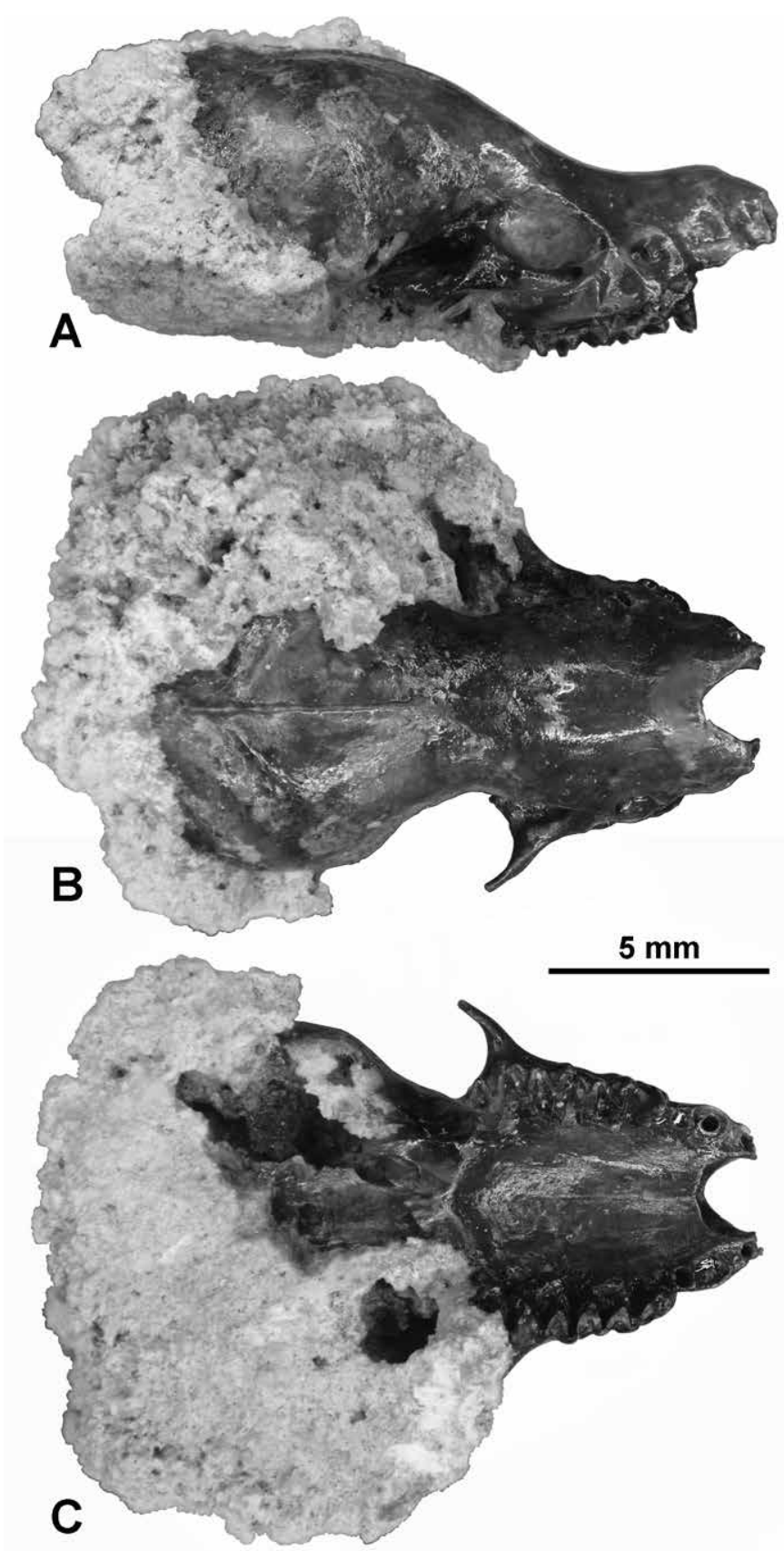

Figure 5. Myotis grisescens cranium with adhering matrix (OMNH 72965) in A, lateral view; B, dorsal view; C, palatal view.
77747-77748, 77848-77850, complete humeri; OMNH not separately listed by number, numerous elements including juveniles with deciduous and unerupted or erupting permanent teeth (e.g., OMNH 77728, Fig. 3F). All of the specimens, complete enough to be identified as this species, came from the Drain.

We used the key provided by Gaudin et al. (2011) for partial help identifying dentaries of Myotis from ThreeForks Cave. Myotis grisescens was largest of their Tennessee species of Myotis among modern specimens measured. This species has a mandibular length greater than or equal to $11.5 \mathrm{~mm}$ whereas Myotis septentrionalis and other eastern species have the mandibular length less than $11.4 \mathrm{~mm}$ (Gaudin et al., 2011). Of these, their smallest species Myotis leibii had an alveolar length (c1$\mathrm{m} 3$ ) less than or equal to $5.0 \mathrm{~mm}$. Between these size extremes, "No current method can be used to unambiguously identify skeletal remains of the other southeastern US species of Myotis to the species level (M. sodalis...M. austroriparius... and $M$. lucifugus.... Therefore, we were unable to distinguish these species in this study" (Gaudin et al., 2011: p. 612).

Of our specimens from Three-Forks Cave referred to the genus Myotis, 41 dentaries were measured for species identification using the criteria provided by Gaudin et al. (2011). Summary measurements of this sample were as follows: mandibular length, $n=18$, observed range $=$ 10.5-14.0, mean $=12.50$; mandibular alveolar toothrow length, $\mathrm{n}=41$, observed range $=5.0-8.1$, mean $=6.82$. The largest of these measurements are consistent with those of Gaudin et al. (2011) to diagnose Myotis grisescens and inconsistent with $M$. septentrionalis, while the smallest are equivalent to $M$. leibii. However, some ThreeForks Cave specimens overlap with $M$. septentrionalis and other species. Nine of the large humeri of Myotis were complete enough for measurements (Table 1) and all are assigned to $M$. grisescens. Thus, $M$. grisescens is probably present, and additional species of Myotis are also likely represented in the sample from Three-Forks Cave, but we cannot identify them with current methods.

Myotis grisescens is the most abundant bat in the Three-Forks Cave sample. Many specimens with erupting permanent teeth indicate use of the cave as a maternity roost in the late Pleistocene. Other specimens exhibit heavy tooth wear and indicate aged individuals, whereas relatively few show light to moderate wear. The most complete cranium (OMNH 72965; Fig. 5) and numerous rostra agree closely with modern specimens of $M$. grisescens in morphology and size. The cranium bears a sagittal crest. One rostrum, OMNH 77733 , has a less abruptly rising forehead profile than the others, and also has somewhat deeper facial concavities anterior to the orbits and above the infraorbital foramina. It is included here with $M$. grisescens because of a lack of other distinguishing features, but possibly represents a second large species of Myotis. Numerous isolated upper molars of bats document a range of sizes, suggesting that more than one species of Myotis is present in the assemblage but not represented by any of the more complete specimens. Evidence for this is the relatively small size of several M1s and M2s with transverse widths of 1.5-1.7 mm (e.g., OMNH 77920, 78178, 78179, 78200) compared to those identified as M. grisescens with transverse widths of $1.7-2.3 \mathrm{~mm}$. We assigned only our largest specimens to M. grisescens, whereas isolated teeth and other elements are assigned to Myotis sp. indeterminate. 
Table 1. Measurements $(\mathrm{mm})$ of adult, complete fossil humeri referred to the species Myotis grisescens from Three-Forks Cave, Oklahoma.

\begin{tabular}{|c|c|c|c|}
\hline Specimen/OMNH No. & Greatest Length & Proximal Width & Distal Width \\
\hline 72969 & 24.9 & 3.7 & 3.5 \\
\hline 72970 & 24.85 & 3.45 & 3.25 \\
\hline 72971 & 24.2 & 3.5 & 3.35 \\
\hline 72972 & 25.15 & 3.45 & 3.2 \\
\hline 77747 & 26.5 & 3.65 & 3.45 \\
\hline 77748 & 24.95 & 3.5 & 3.5 \\
\hline 77848 & 24.8 & 3.7 & 3.75 \\
\hline 77849 & 25.6 & 3.55 & 3.5 \\
\hline 77850 & 24.8 & 3.5 & 3.3 \\
\hline 77863 & 26.65 & 3.75 & 3.5 \\
\hline 77864 & 26.6 & 3.8 & $\cdots$ \\
\hline 77865 & 27.05 & 3.8 & 3.55 \\
\hline 77868 & 23.75 & 3.3 & 3.05 \\
\hline 77870 & 25.3 & 3.7 & 3.55 \\
\hline 78014 & 24.9 & 3.3 & 3.0 \\
\hline 78412 & 27.85 & 3.55 & 3.5 \\
\hline 78413 & 26.5 & 3.55 & 3.35 \\
\hline 78414 & 24.5 & 3.45 & 3.15 \\
\hline 78415 & 25.4 & 3.5 & 2.95 \\
\hline $\begin{array}{l}\text { Total number of samples } \\
\text { Mean of samples }\end{array}$ & $\begin{aligned} \mathrm{N} & =19 \\
\text { Mean } & =25.487\end{aligned}$ & $\begin{array}{c}N=19 \\
\text { Mean }=3.566\end{array}$ & $\begin{array}{c}N=18, \\
\text { Mean }=3.356\end{array}$ \\
\hline
\end{tabular}

Although we did not notice $M$. grisescens using Three-Forks Cave during our paleontological work and no systematic search for them has been done there, the species forms a large maternity colony in another nearby cave on Gittin' Down Mountain (Sasse et al., 2007). They almost certainly also utilize Three-Forks Cave and other caves in the vicinity at times, although we are unaware of their recent use of Three-Forks Cave as a nursery. These bats form part of the historical "Southern Sub-population" of the Ozark population of this endangered species (Sasse et al., 2007).

\section{Carnivora}

Canidae

Canis dirus (dire wolf)

Material: $\mathrm{OMNH} 73039$, right upper canine (Fig. $4 \mathrm{I}, \mathrm{J}$ ), from the Drain.

The tooth shows light wear on the tip and a slight wear facet from contact with the lower canine on its anterior face; there are modest longitudinal ridges running down the mesial and distal surfaces. The complete root is preserved and the pulp cavity is closed, indicating an adult. The crown of the canine measures (APL $\times$ TW) $19.7 \times 14.1$. By comparison, two other C1s of C. dirus from localities of Pleistocene age in Oklahoma (at Burnham and Marlow; Cifelli et al., 2002; Czaplewski, 2003) measure $17.1 \times 12.1$ and $18.7 \times 12.1$, and a C1 from Pul-103 Cave, Pulaski Co., Missouri measured 17.7 x 12.7 (Hawksley et al., 1963). Upper canines of modern Canis lupus are about 2-4 mm smaller in each of these dimensions. Elsewhere in the Ozark Highlands, $C$. dirus is known as a late Pleistocene fossil at 10 localities in Missouri and two in Arkansas (Dundas, 1999).

Vulpini (foxes)

Genus indet.

Material: OMNH 77902, right humerus missing distal end, from the Drain. Measurements of the specimen are proximal articular width, $16.6 \mathrm{~mm}$; midshaft diameter medial-lateral, $7.0 \mathrm{~mm}$; midshaft diameter, anterior-posterior, $9.4 \mathrm{~mm}$.

The humerus is identified as that of a canid based on the lack of an entepicondylar foramen and the presence of a supratrochlear foramen. Its small size further distinguishes it from Canis spp. (coyotes and wolves) as one of the foxes (Vulpes or Urocyon).

\section{Ursidae}

Arctodus simus (short-faced bear)

Material: OMNH 73334, partial skeleton from the Second Parachute Room (consisting of small cranial fragments, partial dentary: left c1, lower incisor, right P4, right M1, right maxillary fragment with alveoli for P1 and P2, P2 or P3; portions of ilium, ischium, head of humerus, right humerus distal fragment, portions of femur, cervical vertebrae, thoracic vertebrae, rib fragments, costal ribs and sternebrae, lumbar vertebra, caudal vertebrae). Nine elements are referred to as a second individual because they were collected from a passage west of the Drain (Fig. 2D). These remains are cataloged separately as OMNH 78515, unworn small P/p2 or P/p3; 73040, thoracic vertebra; 73041, partial ulna; 77897, left proximal radius shaft fragment; 77898, navicular; 77896, right proximal tibia with partial articular surface; 77899 , metatarsal III; 77900, proximal phalanx; 73042, phalanx.

Measurements of teeth associated with the partial skeleton from the Second Parachute Room are: c1 APL 28.6, TW 19.3; P4 APL 21.6, TW 14.9; M1 APL 24.9, TW 23.1; m2 (from Puckette 1976) APL 29.5, TW 19.5. Measurements of the metatarsal III from the Drain are: greatest length 79.4, greatest proximal width 18.0, greatest proximal depth 24.7, 
greatest distal width 18.1. The measurements of the metatarsal III from Three-Forks Cave are smaller than those for two third metatarsals, reported by Merriam and Stock (1925). By comparison with other published measurements, the bears from Three-Forks Cave were both small individuals of $A$. simus.

This species is recognizable by the presence of a deep pre-masseteric fossa in the dentary (Fig. 6G), large size, and cheek teeth morphologically distinct from those of ursine bears. Two individuals of the giant short-faced bear are represented in the faunal assemblage from Three-Forks Cave; parts of each were found in separate rooms (Figs. 2B and 2D) within the cave and show different preservation. One individual, found in a passageway adjacent to the Second Parachute Room (Fig. 2B), is represented by greatly worn teeth and numerous postcranial bones and fragments (OMNH 73334; Figs. 6, 7). The second individual, from a passage near the Drain, comprised a cluster of scattered bones and a little-worn P/p2 or P/p3 (Fig. 8). The former specimen represents associated parts of a senescent individual bear, while the latter cluster of isolated elements represents a younger adult. The former specimen includes a tooth collected years ago and prior to our work in the cave that was previously published by Puckette (1976), conserved in the University of Arkansas Museum (UAM) collection. The specimen from the University of Arkansas consists of a heavily worn m2, UAM catalog number 75-839-1, and was the first record of $A$. simus in Oklahoma. This $\mathrm{m} 2$ is almost certainly associated with the elements collected by us from the same, aged individual, because it shows a similar advanced stage of tooth wear and identical preservation. Thus, parts of this individual are preserved in two different collections, in the University of Arkansas and the Oklahoma Museum of Natural History. In general, preservation of the bones and teeth of the first bear was poorer, with the bones being light in color, much broken and abraded, and with extensive rodent-gnawing on some pieces (Fig. 7D, L). Bones of the second bear were dark brown and some pieces had originally been concreted with calcite (visible on the centrum of the thoracic vertebra, Fig. 8E). Because direct association of the several scattered elements of the second individual of $A$. simus could not be demonstrated, these elements were cataloged separately.

Short-faced bears are hypothesized to have been sexually dimorphic, with males larger than females (Kurtén, 1967; Churcher et al., 1993). The two individuals of $A$. simus in Three-Forks Cave are relatively small and, therefore, likely to represent females; this is consistent with the conclusions of Schubert and Kaufmann (2003) that only females denned in caves. We cannot determine whether the bears used the cave for hibernation, birthing young, or denning. Adjacent to Three-Forks Cave is a small, separate cave that was probably once a part of the same cave complex. It contains a crater-like feature about $2 \mathrm{~m}$ in diameter that represents a possible short-faced bear bed, and other caves in the area may contain them as well (personal observations). By comparison, recent black bear beds in Three-Forks Cave are

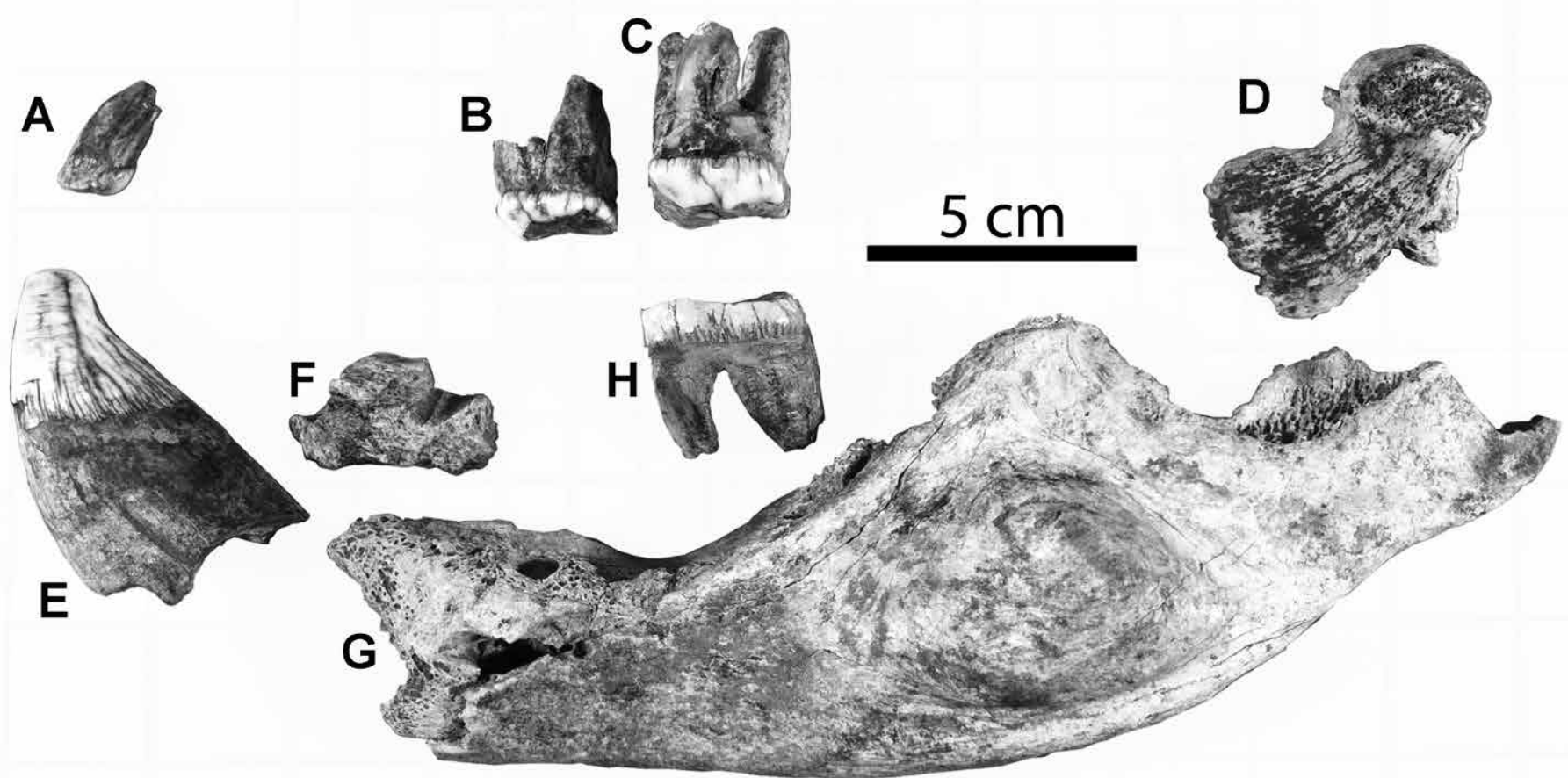

Figure 6. Teeth and dentary fragments of Arctodus simus found near the Second Parachute Room in Three-Forks Cave, Oklahoma. All are cataloged as parts of OMNH 73334 except H. A, upper(?) incisor in lateral view; B, right P4 in lingual view; C, left M1 in lingual view; D, medial end of right condyloid process of dentary in medial view; E, left lower(?) canine in labial view; F, small fragment of right dentary with alveoli for p3 and p4; G, broken and abraded left partial dentary with deep ends of some alveoli forward to the canine alveolus, in lateral view; $\mathrm{H}$, right $\mathrm{m} 2$ (UAM 75-839-1) in labial view. 


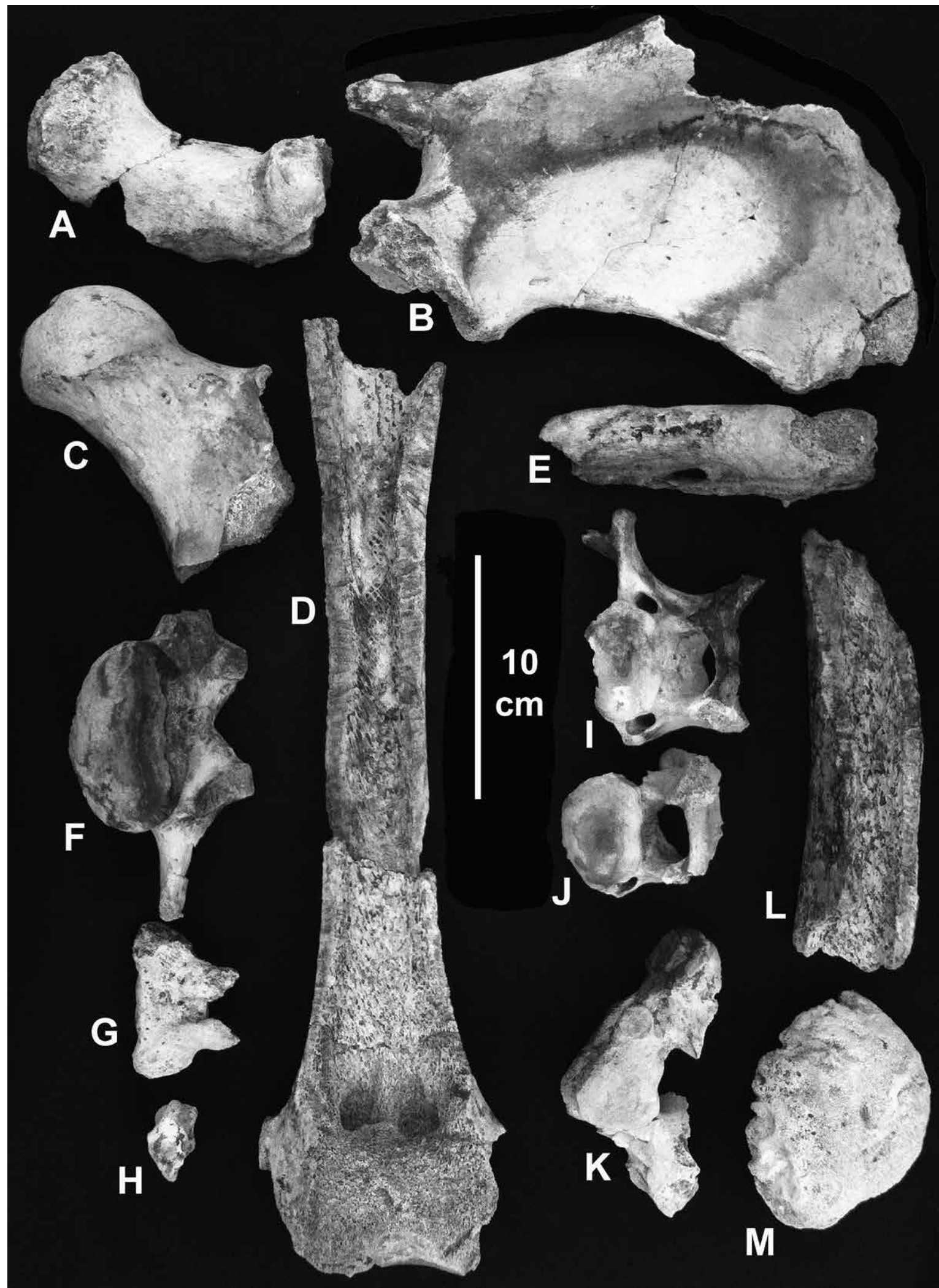

Figure 7. Selected postcranial skeletal elements of Arctodus simus (OMNH 73334) found near the Second Parachute Room in Three-Forks Cave, Oklahoma. A, right ischium in lateral view; B, right ilium in lateral view; C, head of femur in anterior view; D, longitudinally split, posterior and distal portion of the left femur in anterior view, with broken edges of shaft extensively gnawed by rodents and distal portion abraded; $E$, distal fragment of humerus showing entepicondylar foramen in posteromedial view; $F$, partial lumbar vertebra in posterior view; $G$, proximal caudal vertebra in dorsal view; $\mathrm{H}$, mid-caudal vertebra in anterior view; I, J, portions of two cervical vertebrae in posterior view; $\mathrm{K}$, partial thoracic vertebra in anterior view; L, shaft fragment of femur showing extensive rodent gnawing; $M$, right partial head of humerus in proximal view. 


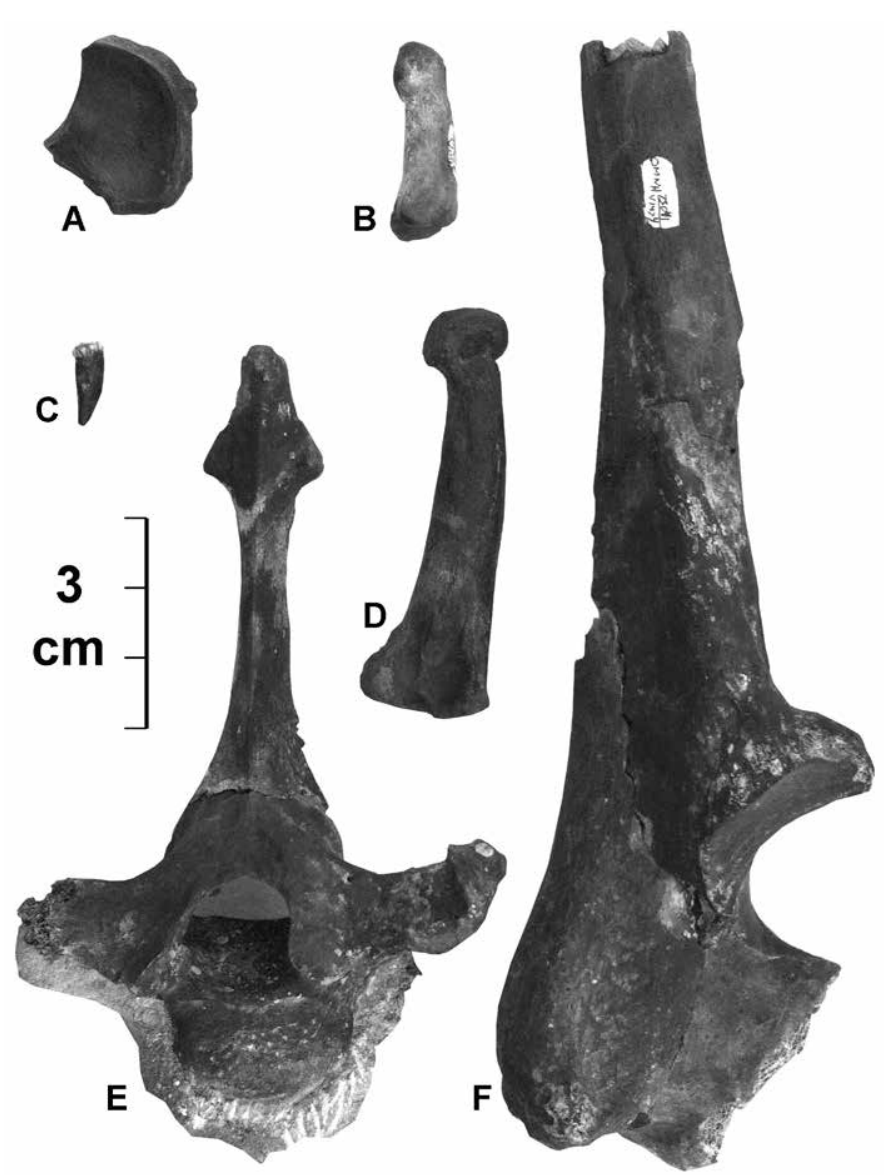

Figure 8. Skeletal elements of Arctodus simus found west of the Drain in Three-Forks Cave, Oklahoma. A, left navicular (OMNH 77898) in proximal view; $\mathrm{B}$, phalanx (OMNH 77900) in lateral view; $\mathrm{C}$, little worn $\mathrm{P} / \mathrm{p} 2$ or $\mathrm{P} / \mathrm{p} 3$ (OMNH 78515) in lateral view; $\mathrm{D}$, left metatarsal III (OMNH 77899) in lateral view; E, thoracic vertebra (OMNH 73040) in anterior view, with adhering calcite on ventral surfaces; F, right partial proximal ulna (OMNH 73041) in medial view.

Material: OMNH 78523, p4, from the Drain.

The $\mathrm{p} 4$ is abraded and polished with all edges rounded, probably from water-wear. Nevertheless, it can be identified as that of Geomys in being hypselodont and bilophodont with wide dentine tracts on either side extending the full height of the crown, a narrow connection between the protolophid and metalophid, and V-shaped re-entrant angles (Hall and Kelson, 1959).

\section{Heteromyidae}

Chaetodipus or Perognathus sp. indet. (pocket mouse)

Material: $\mathrm{OMNH} 78522$, right $\mathrm{m} 1$ or $\mathrm{m} 2$, from the Drain.

Measurements of the molar are APL, 0.95; TW, 1.35. The cheek tooth is rooted, low-crowned, and bunolophodont with two lophs. It bears three well-developed roots, and its occlusal surface is worn such that the protostylid is confluent with metalophid-protoconid. Its measurements are slightly smaller than $\mathrm{m} 1 \mathrm{~s}$ and $\mathrm{m} 2 \mathrm{~s}$ in Chaetodipus hispidus, the species of pocket mouse with a modern distribution nearest to the Ozark Highland in Oklahoma (Caire et al. 1989; Kays and Wilson, 2002). A worn, isolated molar such as this lacks apomorphic morphological characteristics to distinguish between the genera Chaetodipus and Perognathus.

Nevertheless, the pocket mouse specimen, potentially, is biogeographically significant. If it represents a true occurrence in a habitat near the cave, it indicates the extralimital presence of a perognathine in the late Pleistocene of the southwestern Ozark Highlands, where none has occurred in historic times. In modern times, the mouse Chaetodipus hispidus has only been found west of the Neosho-Arkansas Rivers that delimit the western edge of the Ozark Highland in Oklahoma. The species has been recorded as near as 70-90 km west of Three-Forks Cave just west of the Ozark 
Highland (Caire et al., 1989). The species' modern habitat preference suggests an extension of relatively dry, grassy or open plains habitat into the Ozarks during the late Pleistocene. However, the pocket mouse fossil might represent the remains of a prey species brought into the cave from a more distant habitat by a predator such as an owl. Owls can transport prey animals they have ingested for some distance until later egesting a pellet. This phenomenon and the distance involved appears to have received little attention in taphonomic studies of owl pellet accumulations (Andrews, 1990; Walton, 1990; Terry, 2004; Czaplewski, 2011). If an owl moves a great distance in between ingestion and egestion, such as during a migration or a less distant hunting bout, it could potentially accumulate prey from habitats far from the locality where it casts a pellet containing the prey remains. The presence of a great horned owl fossil bone in Three-Forks Cave heightens the possibility, but the owl bone does not demonstrate, that the pocket mouse fossil is an intrusive member of the paleo assemblage of the cave (Andrews, 1990). The species Chaetodipus cf. hispidus was previously recorded in the Ozark Highlands at Crankshaft Cave, Missouri, in the Wisconsinan glacial period (Parmalee et al., 1969; FAUNMAP Working Group, 1994).

Cricetidae

Peromyscini

Peromyscus, Ochrotomys, or Podomys sp. indet. (mouse)

Material: OMNH 77861, left m1; 78525-78526, left M1s; 78527, right M3; 77701-77702, right dentaries with i1; 73038, edentulous maxilla; all from the Drain. OMNH 77699, dentary with i1, from the Second Parachute Room.

Measurements of the molars (APL $\times$ TW) are: $77861,1.50 \times 0.95 ; 78525,1.85 \times 1.10 ; 78526,1.80 \times 1.10 ; 78527$, $0.95 \times \times 0.90$.

The specimens have small, rooted, cuspate, bunodont teeth typical of deer mice and their relatives (Osgood, 1909; Bradley et al., 2007). Based on the paucity of material and the possibility that several different, but morphologically similar, species of Peromyscus and closely-related genera occurred in the vicinity of Three-Forks Cave, it is not possible to refer these few specimens to a genus.

Neotoma cf. floridana (eastern woodrat)

Material: OMNH 77700, left dentary fragment with m1-m3; 78550, left calcaneum; 73019, proximal ulna; 77922, femur; all from the Drain.

The molar teeth are rooted, hypsodont, lophodont and semi-prismatic, which are typical of woodrats that commonly utilize caves and rock shelters across North America (Vaughan et al., 2015). The bilophate $\mathrm{m} 3$ is characteristic of species in the subgenus Neotoma and the $\mathrm{m} 1$ has essentially no anterior lateral dentine tract, consistent with $\mathrm{N}$. floridana (Harris, 2014). The teeth and bones represent a large woodrat the size of recent $N$. floridana (Fig. $3 \mathrm{H}$ ). In addition to the body fossils, several coprolites (OMNH 78551, 78546) from the Drain are similar to scats of Neotoma and probably are attributable to woodrats dwelling in and near the cave in the late Pleistocene. The original scat contents have been replaced by sediment grains, but the contents retain the shape of Neotoma scat pellets as are seen in numerous caves throughout North America.

Arvicolinae

Microtus cf. ochrogaster (prairie vole)

Material: OMNH 78353, right dentary fragment with $\mathrm{m1}$ (Fig. 3C), from the Drain.

The $\mathrm{m} 1$ is hypselodont, with prismatic crown pattern, and bears cementum in the re-entrant angles, characteristic of voles of the genus Microtus (Semken and Wallace, 2002). The crown pattern shows three closed triangles, an anteriorly-rounded anterior loop, and low dentine tracts, typical of the subgenera Pitymys and Pedomys. Enamel is thicker on the forward edges of triangles relative to the rearward edges; the medial portions of the re-entrant angles curve forward or not at all; and the sixth re-entrant angle is shallow. These features are characteristic of Microtus (Pedomys) ochrogaster, but the specimen is only tentatively referred to that species because of variability and overlap of some characteristics with M. (Pitymys) pinetorum (Semken and Wallace, 2002).

\section{Lagomorpha}

Leporidae

Sylvilagus sp. indet. (cottontail rabbit)

Material: OMNH 77732, left p3; 78552, right fifth metatarsal V; 78554, phalanx; from the Drain.

The p3 measures $2.8 \mathrm{~mm} \mathrm{APL} \times 2.7 \mathrm{~mm}$ TW, is hypselodont, heavily invested with cementum anteriorly, labially, and within the re-entrant angles, and has enamel that varies greatly in thickness across the occlusal surface. It shares with Sylvilagus the normal anterior, anteroexternal, and posteroexternal re-entrant angles, as well as weak crenulations of the enamel, including that on the walls of the posteroexternal re-entrant (Hibbard, 1963), but the material lacks species-level diagnostic characters.

\section{Discussion}


Other than four extinct large mammals, none of the vertebrates from Three-Forks Cave became extinct at the end of the Pleistocene. In Three-Forks Cave, these extinct megafaunal members include the ground sloth Megalonyx jeffersonii, the short-faced bear Arctodus simus, the dire wolf Canis dirus, and a horse, family Equidae; indicating a Rancholabrean age for the assemblage. All other taxa, as far as they are identifiable, still occur in the Ozark Highlands today except for one, a pocket mouse of the subfamily Perognathinae, genus Chaetodipus or Perognathus. The pocket mouse suggests either the extralimital occurrence of this mouse in the southwestern Ozark Highlands during the late Pleistocene--and thus a potential extension of relatively dry, grassy or open habitat into the Ozarks--or else it represents the remains of a prey species brought into the cave from a more distant habitat by a predator such as an owl, and, thus, is intrusive. In historic times, the mouse Chaetodipus hispidus has been found as near to Three-Forks Cave in several of the Oklahoma counties immediately west of the edge of the Ozark Highland (Caire et al., 1989). The total of 23 vertebrate taxa in the fauna from Three-Forks Cave makes it the largest known vertebrate assemblage from a cave in the Ozark Highland of Oklahoma, exceeding nearby Sassafras Cave with an assemblage of nine taxa (Czaplewski et al., 2002). Two of the taxa provide the first records of their respective species in the late Pleistocene of Oklahoma, the freshwater drum (Aplodinotus cf. grunniens) and great horned owl (Bubo virginianus).

Among the bat bones, numerous specimens, especially of Myotis grisescens, consisting of jaws and jaw fragments with deciduous teeth, erupting teeth, and enamel caps of upper and lower molars from juveniles (Fig. 3F, G) were recovered. Similarly, less common remains of Eptesicus fuscus, with erupting permanent teeth, occurred in the cave deposits. The fossils of immature individuals indicate the use of Three-Forks Cave as a maternity roost for these two species. Other than the juveniles, specimens of $M$. grisescens include fossils showing stages of tooth wear from slight to heavy, indicating at least some aged adult bats. Of the few bat specimens that could be identified as Perimyotis subflavus, all pertained to young adults with little-worn teeth. All three species of bats found as fossils still occur in Three-Forks Cave today; we also observed Corynorhinus townsendii ingens, the endangered Ozark big-eared bat, in the cave, However, we found no fossils of that species. The fossils indicate that environmental conditions of temperature and humidity, suitable for birthing young bats within Three-Forks Cave in the late Pleistocene, were not so different from today.

Two individuals of the short-faced bear, Arctodus simus, occurred in Three-Forks Cave, as determined by their discovery in two separate parts of the cave, different bone preservation, and different stages of tooth wear, with one having greatly worn teeth and the other preserving a single, lightly worn tooth. Both individuals are relatively small, possibly indicating they were females of this potentially sexually-dimorphic species (Schubert and Kaufmann, 2003). As noted above, several of the bone fragments of $A$. simus are extensively rodent-gnawed, possibly by woodrats living in the cave; their scats were also preserved. Woodrats might also have been responsible for collecting some of the bones in the cave deposits. The owl Bubo virginianus probably contributed to the accumulation of small vertebrate remains. Short-faced bears are thought to have been carnivorous-omnivorous and are implicated as scavengers of large mammal carcasses (Matheus, 1995, 2003; Sorkin, 2006; Figueirido et al., 2010, 2017). Short-faced bears and dire wolves using the cave are additional potential sources of the remains of large mammals (horse, ground sloth), and possibly also of smaller mammals like the fox (Vulpini), brought in as prey remains or scavenged body parts. Large depressions in Three-Forks Cave and other nearby caves resemble beds of denning black bears, except for the much larger size of some, suggesting they could be beds of short-faced bears.

\section{Acknowledgments}

Thanks to Linda DeBerry for her cheerful enthusiasm and help in collecting the fossils in the cave. Thanks to Clayton and Sylvia Russell for access to and help in the cave, for logistical support during this work, and for donating the fossils from the cave to the OMNH. We greatly appreciate Donald R. Russell for all the efforts he made to protect and conserve caves of the Cherokee Nation (Russell, 1971). We extend our sincere thanks to Bill May for picking microfossils from screened concentrate, to Tamaki Yuri for use of the OMNH bird osteology collection, to Jen Larsen for compiling lists of specimens, and to Steve Westrop and Roger Burkhalter for use of their bellows camera. We express our appreciation to Chris Bell, two anonymous reviewers, and Associate Editor Greg McDonald for their time and effort in providing helpful, critical reviews that improved the manuscript from an earlier version.

\section{References}

Akersten, W.A., and McDonald, H.G., 1991, Nothrotheriops from the Pleistocene of Oklahoma and paleogeography of the genus: Southwestern Naturalist, v. 36, p. 178-185. https://doi.org/10.2307/3671918.

Andrews, P., 1990, Owls, Caves, and Fossils: Chicago, University of Chicago Press, 231 p.

Bell, C.J., Head, J.J., and Mead, J.I., 2004, Synopsis of the herpetofauna from Porcupine Cave, in Barnosky, A.D., ed., Biodiversity Response to Climate Change in the Middle Pleistocene: The Porcupine Cave Fauna from Colorado: Berkeley, University of California Press, p. 117-126. https://doi.org/10.1525/california/9780520240827.003.0019; https://doi.org/10.1525/california/9780520240827.003.0011.

Bradley, R.D., Durish, N.D., Rogers, D.S., Miller, J.R., Engstrom, M.D., and Kilpatrick, C.W., 2007, Toward a molecular phylogeny for Peromyscus: evidence from mitochondrial cytochrome-b sequences: Journal of Mammalogy, v. 88, p. 1146-1159. https://doi.org/10.1644/06-MAMMA-342R.1. 
Brasso, R.L., and Emslie, S.D., 2006, Two new late Pleistocene avifaunas from New Mexico: The Condor, v. 108, p. 721-730. https://doi. org/10.1650/0010-5422(2006)108[721: TNLPAF]2.0.CO;2.

Caire, W., Tyler, J.W., Glass, B.P., and Mares, M.A., 1989, Mammals of Oklahoma: Norman, University of Oklahoma Press, 567 p.

Carter, T., Menzel, M., Chapman, B., and Miller, K., 1999, Summer foraging and roosting behaviour of an eastern pipistrelle, Pipistrellus subflavus: Bat Research News, v. 40, p. 5-6.

Churcher, C.S., Morgan, A.V., Carter, L.D., 1993, Arctodus simus from the Alaskan Arctic Slope: Canadian Journal of Earth Sciences, v. 30 , p. 1007-1013. https://doi.org/10.1139/e93-084.

Cifelli, R.L., 1996, Techniques for recovery and preparation of microvertebrate fossils: Norman, Oklahoma Geological Survey Special Publication 96-4, p. 1-36.

Cifelli, R.L., Smith, K.S., and Grady, F.V., 2002, Dire wolf in the Pleistocene of Oklahoma: Norman, Oklahoma Geological Survey Notes, v. 62, p. 92-96.

Czaplewski, N.J., 2003, A dire wolf from the Burnham site, in Wyckoff, D.G., Theler, J.L., and Carter, B.J., eds., The Burnham Site in northwestern Oklahoma: glimpses beyond Clovis?: Norman, Oklahoma Museum of Natural History and Oklahoma Anthropological Society Memoir no. 9, p. 161-167.

Czaplewski, N.J., 2011, An owl-pellet accumulation of small Pliocene vertebrates from the Verde Formation, Arizona, USA: Palaeontologia Electronica v. 14, p. 1-33.

Czaplewski, N.J., and Puckette, W.L., 2015, Late Pleistocene remains of an American black bear (Ursus americanus) and two small vertebrates from an Oklahoma Ozark cave: Norman, Proceedings of the Oklahoma Academy of Science, v. 94, p. 10-27.

Czaplewski, N.J., Puckette, W.L., and Russell, C., 2002, A Pleistocene tapir and associated mammals from the southwestern Ozark Highland: Journal of Cave and Karst Studies, v. 64, p. 97-107.

Dundas, R.G., 1999, Quaternary records of the dire wolf, Canis dirus, in North and South America: Boreas, v. 28, p. 375-385. https://doi. org/10.1111/j.1502-3885.1999.tb00227.x; https://doi.org/10.1080/030094899422109.

Emslie, S.D., 1985, The late Pleistocene (Rancholabrean) avifauna of Little Box Elder Cave, Wyoming: Contributions to Geology, University of Wyoming, v. 23, p. 63-82.

Emslie, S.D., and Heaton, T.H., 1987, The late Pleistocene avifauna of Crystal Ball Cave, Utah: Journal of the Arizona-Nevada Academy of Science, v. 21, p. 53-60.

Farrow, L.J., and Broders, H.G., 2011, Loss of forest cover impacts the distribution of the forest-dwelling tri-colored bat (Perimyotis subflavus): Mammalian Biology, v. 76, p. 172-179. https://doi.org/10.1016/j.mambio.2010.04.004.

FAUNMAP Working Group, 1994, Faunmap: A Database Documenting Late Quaternary Distributions of Mammal Species in the United States: Springfield, Illinois State Museum, Scientific Papers, v. 25, nos. 1 \& 2, p. 1-690. http://www.ucmp.berkeley.edu/faunmap/, http://www.ucmp. berkeley.edu/faunmap/about/index.html

Figueirido, B., J.A. Pérez-Claros, V. Torregrosa, A. Martín-Serra, and P. Palmqvist. 2010. Demythologizing Arctodus simus, the 'short-faced' long-legged and predaceous bear that never was: Journal of Vertebrate Paleontology, v. 30, p. 262-275. https://doi. org/10.1080/02724630903416027.

Figueirido, B., Pérez-Ramos, A., Schubert, B.W., Serrano, F., Farrell, A.B., Pastor, F.J., Neves, A.A., and Romero, A., 2017, Dental caries in the fossil record: a window to the evolution of dietary plasticity in an extinct bear: Scientific Reports, v. 7:17813, p. 1-7. https://doi.org/10.1038/ s41598-017-18116-0.

Gaudin, T.J., Miller, A.N., Bramblett, J.L., and Wilson, T.P., 2011, Holocene and late Pleistocene bat fossils (Mammalia: Chiroptera) from Hamilton County, TN, and their ecological implications: Southeastern Naturalist, v. 10, p. 609-628. https://doi.org/10.1656/058.010.0403.

Green, M., 1941, The cranial and appendicular osteology of Aplodinotus grunniens Rafinesque: Lawrence, Transactions of the Kansas Academy of Science, v. 44, p. 400-414. https://doi.org/10.2307/3624913.

Guilday, J.E., Parmalee, P.W., and Hamilton, H.W., 1977, The Clark's Cave bone deposit and the late Pleistocene paleoecology of the Central Appalachian Mountains of Virginia: Pittsburgh, Bulletin of Carnegie Museum of Natural History, v. 2, p. 48-51.

Hall, E.R., and Kelson, K.R., 1959, The Mammals of North America. Volume 1: New York, Roland Press, 546 p.

Harris, A.H., 2014, Pleistocene Vertebrates of Southwestern USA and Northwestern Mexico: El Paso, University of Texas at El Paso, Digital book downloaded at http://digitalcommons.utep.edu/bio_papers/120/ [accessed May 3, 2017]

Hawksley, O., Reynolds, J., and McGowan, J., 1963, The dire wolf in Missouri: Missouri Speleology, v. 5, p. 63-72.

Heintzman, P.D., Zazula, G.D., MacPhee, R. D. E., Scott, E., Cahill, J.A., McHorse, B.K., Kapp, J.D., Stiller, M., Wooler, M.J., Orlando, L., Southon, J., Froese, D.G., and Shapiro, B., 2017, A new genus of horse from Pleistocene North America: eLife 2017, v. 6:e29944, p. 1-43.

Hibbard, C.W., 1963, The origin of the p3 pattern of Sylvilagus, Caprolagus, Oryctolagus, and Lepus: Journal of Mammalogy, v. 44, p. 1-15. https://doi.org/10.2307/1377162.

Hoganson, J W., and McDonald, H.G., 2007, First report of Jefferson's ground sloth (Megalonyx jeffersonii) in North Dakota: paleobiogeographical and paleoecological significance: Journal of Mammalogy, v. 88, p. 73-80. https://doi.org/10.1644/06-MAMM-A-132R1.1.

Holman, J.A., 1995, Pleistocene Amphibians and Reptiles in North America: New York, Oxford University Press, 243 p.

Holman, J.A., 2000, Fossil Snakes of North America: Origin, Evolution, Distribution, Paleoecology: Bloomington and Indianapolis, Indiana University Press, $357 \mathrm{p}$.

Howard, H., 1929, The avifauna of Emeryville Shellmound: University of California Publications in Zoology, v. 32, p. 301-394.

Howard, H., 1952, The prehistoric avifauna of Smith Creek Cave, Nevada, with a description of a new gigantic raptor: Los Angeles, Bulletin of the Southern California Academy of Sciences, v. 51, p. 50-54.

Hulbert, R.C., Jr., 2001, The Fossil Vertebrates of Florida: Gainesville, Florida, University Press of Florida, 351 p.

Jacquemin, S.J., Ebersole, J.A., Dockinson, W.C., and Ciampaglio, C.N., 2016, Late Pleistocene fishes of the Tennessee River Basin: An analysis of a late Pleistocene freshwater fish fauna from Bell Cave (site ACb-2) in Colbert County, Alabama, USA: Peer J, v. 4, e1648. https://doi. org/10.7717/peerj.1648.

Kays, R.W., and Wilson, D.E., 2002, Mammals of North America: Princeton, Princeton University Press, 240 p.

King, J.E., 1973, Late Pleistocene palynology and biogeography of the western Missouri Ozarks: Ecological Monographs, v. 43, p. 539-565. https://doi.org/10.2307/1942305.

Kurtén, B., 1967, Pleistocene bears of North America. 2. Genus Arctodus, short-faced bears: Acta Zoologica Fennica, v. 117, p. 1-58.

Matheus, P.E., 1995, Diet and co-ecology of Pleistocene short-faced bears and brown bears in Eastern Beringia: Quaternary Research, v. 44, p. 447-453. https://doi.org/10.1006/qres.1995.1090. 
Matheus, P.E., 2003, Locomotor adaptations and ecomorphology of short-faced bears (Arctodus simus) in eastern Beringia: Whitehorse, Palaeontology Program, Government of the Yukon, Occasional Papers in Earth Sciences, no. 7, p. 1-126.

McDonald, H.G., 1977, Osteology of the extinct gravigrade edentate Megalonyx with observations on its taxonomy, ontogeny, phylogeny and functional anatomy. [M.S. thesis]: Gainesville, University of Florida, p. 1-329.

McDonald, H.G., and Jefferson, G.T., 2008, Distribution of Pleistocene Nothrotheriops (Xenarthra, Nothrotheriidae) in North America: Los Angeles, Natural History Museum of Los Angeles County, Science Series no. 41, p. 313-331.

Mead, J.I., Arroyo-Cabrales, J., and Johnson, E., 1999, Pleistocene lizards (Reptilia: Squamata) from San Josecito Cave, Nuevo León, Mexico: Copeia, v. 1999, p. 163-173. https://doi.org/10.2307/1447397.

Merriam, J.C., and Stock, C., 1925, Relationships and structure of the short-faced bear, Arctotherium, from the Pleistocene of California: Washington, Carnegie Institution of Washington, Publication no. 347, p. 1-36.

Miller, L., 1943, The Pleistocene birds of San Josecito Cavern, Mexico: Berkeley, University of California Publications in Zoology, v. 47, p. 143-167.

Miller, L., and DeMay, I., 1942, The fossil birds of California: an avifauna and bibliography with annotations: Berkeley, University of California Publications in Zoology, v. 47, p. 47-142.

Osgood, W.H., 1909, Revision of mice of the American genus Peromyscus: North American Fauna, v. 28, p. 1-285. https://doi.org/10.3996/ nafa.30.0001; https://doi.org/10.3996/nafa.28.0001.

Page, L.M., and Burr, B.M., 1991, A Field Guide to Freshwater Fishes North America North of Mexico: Boston, Houghton Mifflin Company, 432 p.

Parmalee, P.W., Oesch, R. D., and Guilday, J.E., 1969, Pleistocene and recent vertebrate faunas from Crankshaft Cave, Missouri: Springfield, Illinois State Museum, Reports of Investigations, no. 14, p. 1-37.

Paula Couto, C. de, 1976, The manus of Nothrotheriops shastense (Sinclair, 1905): Anais do XXVIII Congresso Brasileiro de Geologia, no. 2, p. 165-176.

Perry, R.W., and Thill, R., 2007, Tree roosting by male and female eastern pipistrelles in a forested landscape: Journal of Mammalogy, v. 88 , p. 974-981. https://doi.org/10.1644/06-MAMM-A-215R.1.

Puckette, W.L., 1976, Notes on the occurrence of the short-faced bear (Arctodus) in Oklahoma: Norman, Proceedings of the Oklahoma Academy of Science, v. 56, p. 67-68.

Qadri, S.U., and McAllister, D.E., 1967, Fish remains from a 700-year-old southern Ontario archaeological site: Ottawa, National Museum of Canada, Natural History Papers, no. 34, p. 1-6.

Richards, R.L., Churcher, C.S., and Turnbull, W.D., 1996, Distribution and size variation in North American short-faced bears, Arctodus simus, in Stewart, K. M., and Seymour, K. L., eds., Palaeoecology and Palaeoenvironments of Late Cenozoic Mammals: Tributes to the Career of C.S. (Rufus) Churcher: Toronto, University of Toronto Press, p. 191--246.

Russell, D.R., 1971, An Essay on the Caves of the Cherokee Nation: Stilwell, Oklahoma, privately published, $50 \mathrm{p}$.

Sasaki, K., 1989, Phylogeny of the family Sciaenidae, with notes on its zoogeography (Teleostei, Perciformes): Hokkaido, Japan, Memoirs of the Faculty of Fisheries, Hokkaido University, v. 36, p. 1-137.

Sasse, D.B., Clawson, R.L., Harvey, M.J., and Hensley, S.L., 2007, Status of populations of the endangered gray bat in the western portion of its range: Southeastern Naturalist, v. 6, p. 165-172. https://doi.org/10.1656/1528-7092(2007)6[165:SOPOTE]2.0.CO;2.

Schubert, B.W., 2010, Late Quaternary chronology and extinction of North American giant short-faced bears (Arctodus simus): Quaternary International, v. 217, p. 188-194. https://doi.org/10.1016/j.quaint.2009.11.010.

Schubert, B.W., and Kaufmann, J.E., 2003, A partial short-faced bear skeleton from an Ozark cave with comments on the paleobiology of the species: Journal of Cave and Karst Studies, v. 65, p. 101-110.

Semken, H.A., Jr., Graham, R.W., and Stafford, T.W., Jr., 2010, AMS ${ }^{14} \mathrm{C}$ analysis of late Pleistocene non-analog faunal components from 21 cave deposits in southeastern North America: Quaternary International, v. 217, p. 240-255. https://doi.org/10.1016/j.quaint.2009.11.031.

Semken, H.A., Jr., and Wallace, S C., 2002, Key to arvicoline ("microtine" rodents) and arvicoline-like lower first molars recovered from late Wisconsinan and Holocene archaeological and palaeontological sites in eastern North America: Journal of Archaeological Science, v. 29, p. 23--31. https://doi.org/10.1006/jasc.2001.0680.

Smith, C.L., 1954, Pleistocene fishes of the Berends fauna of Beaver County, Oklahoma: Copeia, v. 1954, p. 282-289. https://doi. org/10.2307/1440043.

Smith, K.S., and Cifelli, R.L., 2000, A synopsis of the Pleistocene vertebrates of Oklahoma: Norman, Oklahoma Geological Survey Bulletin, v. 147, p. 1-36.

Sobolik, K.D., and Steele, D.G., 1996, A Turtle Atlas to Facilitate Archaeological Identifications: Rapid City, South Dakota, Mammoth Site of Hot Springs, p. 1-117.

Sorkin, B., 2006, Ecomorphology of the giant short-faced bears Agriotherium and Arctodus: Historical Biology, v. 18, p. 1-20. https://doi. org/10.1080/08912960500476366.

Stock, C., 1925, Cenozoic gravigrade edentates of western North America with special reference to the Pleistocene Megalonychinae and Mylodontidae of Rancho La Brea: Washington, Carnegie Institution of Washington, Publication no. 331, p. 1-206 + 47 plates.

Terry, R., 2004, Owl pellet taphonomy: a preliminary study of the post-regurgitation taphonomic history of pellets in a temperate forest: Palaios, v. 19, p. 497-506. https://doi.org/10.1669/0883-1351(2004)019\%3C0497:OPTAPS\%3E2.0.CO;2.

Vaughan, T.A., Ryan, J.M., and Czaplewski, N.J., 2015, Mammalogy, sixth edition: Burlington, Massachusetts, Jones and Bartlett Learning, p. $1-755$.

Veilleux, J.P., Whitaker, J.O., and Veilleux, S.L., 2003, Tree-roosting ecology of reproductive female eastern pipistrelles, Pipistrellus subflavus, in Indiana: Journal of Mammalogy, v. 84, p. 1068-1075. https://doi.org/10.1644/BEM-021.

Veilleux, J.P., Whitaker, J.O., and Veilleux, S.L., 2004, Reproductive stage influences roost use by tree roosting female eastern pipistrelles, Pipistrellus subflavus: Ecoscience, v. 11, p. 249-256. https://doi.org/10.1080/11956860.2004.11682830.

Walton, A.H., 1990, Owl pellets and the fossil record, in Boucot, A.J., ed., Evolutionary Paleobiology of Behavior and Coevolution: Amsterdam, Elsevier, p. 233-241. 
